Perceptions on the Use of English as the Lingua Franca in Nigeria 


\title{
Literacy Instructors' Perception on the Use of English as the Lingua Franca in Nigeria
}

\author{
T. Adepoju \\ Department of Adult Education \\ University of Ibadan, Ibadan - Nigeria \\ Email:tunpoj@yahoo.com
}

\begin{abstract}
The study investigated literacy instructors' perception on the use of English as the lingual franca in Nigeria. Using a descriptive survey design, 126 literacy instructors (43 males and 83 females) randomly drawn from 20 adult literacy centers in Ibadan metropolis, Oyo state constituted the sample. Instructors' English Language Perception Scale (IELPS) with $\mathrm{r}=0.84$ was used to collect the relevant data needed to provide answers to the two research questions raised for the study. Data were analyzed using descriptive statistics of frequency counts, percentages and weighted mean scores. The results reveled that literacy instructors have a favourable (positive) perception on the use of English as the lingual Franca in Nigeria. Some implications for adult English learning were discussed.
\end{abstract}

Keywords: Instructor, perception, lingua franca, multi-lingual.

\section{BACKGROUND}

With a population of about 140 million people (National Population CensusNPC, 2006), Nigeria has between 400 and 410 languages (Ouane, 2003), which accounts for about $25 \%$ of all languages in Sub-Saharan African (Eze, 2003), thus, Nigeria is multi-lingual. Three (3) of the languages namely, Hausa, Yoruba and Igbo, account for 65 percent of Nigeria's population of about 140 million implying that at least, 397 languages are languages of minorities and each of these languages consist of several hundreds of dialects, sociolects, styles and registers. Thus, multi-lingualism as observed by Fyle (2003), is the root of the problems of language education in Sub-Saharan Africa, Nigeria inclusive. This is because the plurality that exists is in fact, not always a diversity of equals, meaning equity of difference, nor does it always represent the full range of a single culture (Kalantzis; Cope, \& Slade, 1989). 
English, the official language, has grown functionally in most domains since its entrenchment during colonialism and later, through policies giving it further power and prestige above the indigenous languages, especially, in the domain of education (Adegbija, 2003). Such language policies, in addition to the official functions which English is seen to perform, have, over the years, built up a favourable attitude towards English, especially, in the education domain.

As a former British colony therefore, Nigeria (borrowing Wolf's 2003 expression), shares with other African countries, one particular blessing or burden (depending on how one looks at it), the use of English as the official language that is, lingual Franca. This paper therefore, sought to investigate literacy instructors' perception on the use of English as Nigeria's lingual Franca. Flowing from this, the study is therefore, premised on two questions:

1. What is the perception of literacy instructors on the use of English as lingual Franca in Nigeria?

2. Is it possible to replace English with one of the indigenous languages as lingual franca in Nigeria

\section{METHODOLOGY}

\section{Design}

This is a descriptive study and it adopts a survey approach.

\section{Sample}

Participants were 126 literacy instructors $($ male $=43$; female $=83$ ); from 20 adults literacy centers distributed across the 5 local government areas that constitute Ibadan metropolis. Their ages ranged from 25 to 54 years (with a mean age of 40.2 years and a standard deviation of 9.96); and working experience as literacy instructors ranged from 2 to 21 years.

\section{Instrument}

Instructors English Language Perception Scale (I.E.L.P.S) was the main instrument designed and used for data collection. This is a 15-item instrument made up of three parts. Part A sought for bio-data information such as sex, age and teaching experience. Part B is a 7-item sub-set placed on a 4-point ordinal scale of Strongly Agree; Agree; Disagree and Strongly Disagree. Respondents were to indicate the degree of their agreements or otherwise to the expressed viewpoints meant to capture their perception on the use of English as lingual franca. Part $\mathrm{C}$ consisted of 5-items on a dichotomized response type of Yes or No options.

I.E.L.P.S was properly validated as both content and construct validity were taken care of through peer review after which the instrument was pilot-tested 


\section{T. Adepoju}

on 20 literacy instructors from 5 randomly selected literacy centers outside Ibadan metropolis. I.E.L.P.S has a reliability estimate (using Cronbach alpha measure) of 0.84

\section{Results and Discussion}

Table I provides the answer to the question of perception on the use of English as the lingual franca.

\begin{tabular}{lllllllllll}
\multicolumn{2}{c}{ Table .1: Perception on the Use of English as the Lingual Franca } \\
\hline S/N
\end{tabular}

Table I shows that adult literacy instructors have a favourable perception on the use of English as lingual franca in Nigeria through:

1. the multiplicity of language in Nigeria which makes English a natural choice as a lingual franca - W.M.S $=3.34$

2. the fact that English has come a long way in Nigeria through colonialism - W.M.S $=2.03$

3. the fact that English is needed to learn other school subjects W.M.S $=3.57$

4. the fact that the English is the only visible sign of literacy in Nigeria - W.M.S = 3.32

5. the fact that English is needed for wider communication both within and outside our national boarders - W.M.S $=2.83$

6. the fact that English is the language of science and technology W.M.S $=3.79$

7. the fact that none of our indigenous languages yet can be used as the language of education, commerce, administration and justice W.M.S $=2.9$

The main focus of this study was to access literacy instructors' perception on the use of English as the lingual franca in Nigeria. The result shows that respondents hold identical viewpoints about the use of English as lingual Franca. The result has thrown more light on the circumstances that favoured 
the use of English as lingual Franca in Nigeria such as multiplicity of languages; long years of use, use as a language of wider communication and that of science and technology among others.

This result supports Bamgbose's (1971) submission that English is the handy linguistic tool linking several millions of people who have about 400 indigenous languages which are not mutually intelligible. Also, the present findings corroborates the position of Adepoju (1996), who opined that if students lack the linguistic skills to undertake special training, technological advancement becomes impossible because any scientist or technologist who lacks a functional knowledge of English remains cut-off from half or more of the world's literature in his field.

In addition, the present finding is in line with the earlier finding of Adepoju (2004), that English is the visible sign of literacy in Nigeria. This is because no person is seen as literate, if such a person can not read and write and/or understand and communicate in English. This is also quite in tune with Ouane's (2003) observation that a language having several functions inevitably gains in prestige, and with its prestige growing, it beats a path towards new functions. This is the case with the English language in Nigeria. Table II provides the information on whether it is possible to replace English with one of the indigenous languages as lingual Franca in Nigeria

\begin{tabular}{|c|c|c|c|c|c|}
\hline \multirow[t]{2}{*}{$S / N$} & \multirow[t]{2}{*}{ Statement } & \multicolumn{2}{|l|}{ Yes } & \multicolumn{2}{|l|}{ No } \\
\hline & & $N$ & $\%$ & $N$ & $\%$ \\
\hline 1. & $\begin{array}{l}\text { There is no indigenous language that can replace English as the lingual franca in } \\
\text { Nigeria }\end{array}$ & 112 & 88.89 & 14 & 11.11 \\
\hline 2 & There is no indigenous language that can be acceptable to all Nigerians & 81 & 64.29 & 45 & 35.71 \\
\hline 3 & $\begin{array}{l}\text { There is no indigenous language that has the quality and credibility of becoming } \\
\text { a lingual franca }\end{array}$ & 101 & 80.16 & 25 & 19.84 \\
\hline 4 & $\begin{array}{l}\text { The use of an indigenous language carries with it the danger of international } \\
\text { isolation }\end{array}$ & 70 & 55.56 & 56 & 44.44 \\
\hline 5 & $\begin{array}{l}\text { The choice of an indigenous language may lead to socio-political unrest and } \\
\text { suspicion }\end{array}$ & 93 & 73.81 & 33 & 26.19 \\
\hline
\end{tabular}

The result as can be seen on table II revealed that there is no possibility of replacing English with an indigenous language as lingual franca because there is no indigenous language that can replace English as the lingual franca. ( $\mathrm{Yes}=88.89 \%$; $\mathrm{No}=11.11 \%$ ); there is no indigenous language that can be acceptable to all Nigerians (Yes $=64.29 \%, \mathrm{No}=35.71 \%$ ); there is no indigenous language that has the quality and credibility of becoming a lingual Franca $(\mathrm{Yes}=80.16 \%$; $\mathrm{No}=19.84 \%)$; the use of indigenous language carries with it, the danger of international isolation ( $\mathrm{Yes}=55.56 \%$; $\mathrm{No}=44.44 \%$ ), and the choice of an indigenous language may lead to socio-political unrest and suspicion $(\mathrm{Yes}=73.81 \%$; $\mathrm{No}=26.19 \%)$.

The result is an affirmation of the age-long fact that at independence, Nigeria deliberately opted for English as the national lingual franca with the obvious aim of encouraging national unity. This is quite in agreement with the submission of Abdulaziz (2003) that the choice of a national language is a sensitive political issue in multi-lingual countries, because nobody wants the 


\section{T. Adepoju}

language of another ethnic group to be chosen; as this will give a special advantage to the native speakers of that language.

Besides, no indigenous language in Nigeria, meets the criteria set by Fasold (1984) to the extent that such language must serve as a symbol of national unity and identity, its must be in everyday life; it must be spoken fluently and with ease by a sizeable proportion of the population; it must be acceptable as a symbol of authenticity; and it must be seen as a link with the glorious past (Fasold, 1984, P. 74). The reality of the above, therefore, makes the replacement of English with an indigenous language as a lingual franca in Nigeria rather a Herculean task.

\section{CONCLUSION}

In conclusion therefore, this study has shown that literacy instructors have a favourable (positive) perception on the use of English as the lingual franca in Nigeria. The study revealed that literacy instructors perceived English as playing a significant role in Nigeria and that the language is yet to have a possible replacement from among the over 400 indigenous languages in the country. Hence, considerable attention needs to be given to adult English teaching and learning.

\section{REFERENCES}

Abdulazis, M. (2003). "The History of Language Policy in Africa with Reference to Language Choice in Education". in Quene, A. (ed) Towards a Multi-Lingual Culture of Education. Hamburg: Unesco Institute for Education

Adegbija, E. (2003). Central Language Issues in Literacy and basic Education: The Mother Tongue Education Experiments in Nigeria" in Quene, A. (ed) Towards a Multi-Lingual Culture of Education. Hamburg: Unesco Institute for Education

Adepoju, T. (1996). "Sex Differences and pupils Performance in English and Mathematics" in Ayodele, S.O (ed.) Education in the Service of Humanity. Ibadan. Institute of Education, University of Ibadan

Adepoju, T. (2004). "Some Correlates of Girls and Women's Attitude to Literacy". International Journal of Literacy and Development. Vol., No.1

Bamgbose, A. (1977). "The English Language in Nigeria" in J. Spencer (ed.) English Language in West Africa. London: Longman Press.

Eze, C.N (2008). "English in the face of Global multi-Cultural Emphasis and challenges of Bilingual Education". August 11, 2008. Http://www.assitnews.net

Fasold, R. (1984). The Socio-Linguistics of Society. Oxford: Blackwell 
Fyle, C.N (2003): Language Policy and Planning for Basic Education in Africa" in Quene, A. (ed) Towards a multi-Linguistics Culture of Education. Hamburg: Unesco Institute for Education

Kalantzis, M.; Cope, B.I and Slade, D. (1989), Minority Language and Determinant Culture. London; New York, Philadelphia: The Falmer Press.

National Population Census (2006). 2006 Census Report.

Quene, A. (2003). Introduction: The View from Inside Linguistic Jail. In Towards a Multi-Lingual Culture of Education. Hamburg: Unesco Institute for Education

Wolf, E. (2003). "The Issue of Language in Democratization: The Niger Experience in literacy and Basic Education" in Quene, A. (ed) Towards a Multi-Lingual Culture of Education. Hamburg: Unesco Institute for Education 